Ivanová Eva,

PhD, Assistant Professor of the Department of Economics and Economy, Faculty of Social and Economic Relations, Alexander Dubček University in Trenčín (Trenčín, Slovak Republic);

Kordoš Marcel, PhD, Assistant Professor of the Department of Public Administration and Regional Economy Faculty of Social and Economic Relations, Alexander Dubček University in Trenčín (Trenčín, Slovak Republic)

\title{
COMPETITIVENESS AND INNOVATION PERFORMANCE OF REGIONS IN SLOVAK REPUBLIC ${ }^{1}$
}

The paper deals with the competitiveness and innovation performance that are two interrelated economic categories being reflected by their synergistic effect in various areas of economic and social life. Their examination and evaluation can be assessed at different levels such as business, regional, national and international level. National competitiveness and innovation performance are results of integral action of stakeholders at business and regional levels. The subject of this paper is to explore the innovative performance at regional level, i.e. at the level of Slovak particular regions on the basis of selected results of innovation processes in the field of science, research and development. Results of innovation performance assessment show strong differences in regions being assessed what is also reflected in their economic performance and competitiveness differences.

Keywords: innovation, innovation performance, competitiveness, region, research, development.

DOI: 10.21272/mmi.2017.1-13

Introduction. More and more increasingly important role of regions in economic development of national economies is one of the accompanying effects of expanding globalization. Increasing regional competitiveness is based on the ability to execute innovation policy objectives in context of national or regional innovation system. National innovation policies that are closely linked to regional innovation policy, and are based on EU innovation policy are supposed to increase competitiveness of regions by means of their innovation performance increase. European Union Innovation policy appears to be an important instrument how to enhance the economic performance because it affects structural policies and structural reforms.

As competitiveness assessment as innovation assessment can be carried out at two basic levels, specifically at micro (enterprise) level or macroeconomic (regional, global) level. At microeconomic level innovation can be measured by research and development results, production factors efficiency, customers' satisfaction, innovation and technology transfers, staff motivation and so on. At company level, for example, it includes new products sale revenues, research and development expenses, new product life cycle length, number of patents, new production and information technologies implementation. At macroeconomic level, the assessment and measurement deals with the competitive advantages of regions and countries. In this case innovation is usually assessed by a variety of settings and indicators set beforehand being engaged in technologies [12].

Options how to express competitiveness of regions and territories are various as well as approaches to the very nature and existence of competitiveness of territories, regions and nations. Some authors see the term competitiveness being used with regards to territorial units as not right. Krugman explains the inadequacy to use parallels between national economy and businesses, because if company is not successful on market the company must leave it and in extreme cases close down business, but region

1 The paper was written under the project VEGA № 1/0233/16: "Dimensions and factors of social and economic development of regions in Visegrad Four countries" 
cannot do this [10]. The difference is in the competition demonstration as a basis for competitiveness. The company's performance improvement and its market position (competitiveness) logically result in worse position of other competing companies. However, if region or country is successful better conditions for development of other regions or countries are to be created. As Haviernikova states territorial unit performance improvement does not mean making worse in performance of other one, in different way successful regions are creating a successful national economy [7].

Regional competitiveness is to be understood in terms of European Commission as "the ability of regions to produce goods and services which are ahead of competition on international markets, while at the same time they maintain a high and sustainable level of income for population in region" [5].

The subject of this paper is to assess the regional innovation efficiency as a key factor how to increa competitiveness of regions.

Theoretical background and literature overview. The word "innovation" is derived from Latin word "innovation" and means "restoration". In most scientific disciplines it is referred to a planned, managed and implemented change in terms of a new system or its better state. In the area of manufacturing companies it is usually all about a new quality product creation and implementation, new production process or new organization methods such as marketing and management. Innovation is an appreciation of creativity and invention. The main impetus for innovation is usually customer's interest in higher quality, products utility value or research and development results leading to the following four types of innovation: innovation within product, process, organization and marketing. The founder of innovation theory is considered Joseph Schumpeter, who in 1934 formulated the concept of innovation what meant "a new combination of development changes". He identifies the following five typical changes [15]:

- the use of new technology, production processes and production marketing management;

- new products implementation, respectively former products with new properties;

- the use of new sources and materials;

- changes in production, distribution and sales organization;

- new markets finding, changes in market structure.

Significant place in innovation theory belongs to works of academic Valenta. They are still actual in terms of systematic approaches, defining of key areas and issues conclusions. This also applies to systematic and general concept of innovation that Valenta sees as "a change in original structure of production organism, as a transition to the new state of its internal structure" [21]. Different approaches to definition of innovation and its various forms can be found in various authors. By Lundvall innovation is the way of new products and services, or resources being placed on market, or the initial new products and processes being set on market, also a process leading from the creative kind of idea to its commercial use [11].

Innovation can be defined as process by which the company put into practice products and manufacturing processes models being new to them, regardless of being new also in the world. Then we talk about the first product launching by a company on market as well as technology dissemination [4]. The issue of regional innovation performance we can find in works of following authors: Fojtikova, Tödtling a Trippl, Urbančíková, Skokan $[6 ; 17 ; 19 ; 20]$. Porter also was dealing with the issue of innovation in terms of defining the concept of national competitiveness as a key capability of nation (country) to innovate and hence to gain the competitive advantage [13].

Michael Porter in his very influential work, The Competitive Advantage of Nations, identified innovations as the competitive advantage of geographic or entrepreneurial units. National prosperity is created, not inherited. It does not grow out of country's natural endowments, its labor pool, its interest rates, or its currency's value, as classical economics insists. Nation's competitiveness depends on the capacity of its industry to innovate and upgrade [13]. 
From Drucker's perspective, systematic innovation consisted of the purposeful and organized search for changes, and in the systematic analysis of the opportunities such changes might offer for economic or social innovation. Furthermore, Drucker says: "Innovation is the specific function of entrepreneurship, whether in an existing business, a public service institution, or a new venture started by a lone individual in the family kitchen. It is the means by which the entrepreneur either creates new wealth-producing resources or endows existing resources with enhanced potential for creating wealth" [3].

There are numerous alternative definitions of innovation. One popular alternative is to present innovation as an invention that has been exploited commercially [12]. The category of innovation is further defined in the Oslo Manual, Frascati Manuáli (OECD) and in Slovak Republic in the Act of 172/2005 Coll. on Organization of state support for research and development and in Amendments to the Act of 575/2001 Coll. on Government activities organization and Central state administration organization.

Kačírková deals with the issue of innovation at regional level, as an important factor for success in a regional context she points out the regional innovation potential level [8]. Regional innovation capacity means an interconnection and innovation potential engagement, like businesses and other regional organizations, into an interactive collaboration. It is created by innovation potential of individual stakeholders in a complex innovation network that is able to achieve much more than its component parts (elements) by themselves [9]. Regional innovation potential involves many factors and activities and its priority function is to increase internal and external interactions of particular actors. It has been defined as a way, method of regional innovation capabilities to utilize and regenerate existing resource base layout and create sustainable competitive advantage within innovation activities [18].

According to Ručínska the innovation performance of economy or economic entity can be assessed by means of innovation systems consisting of regional actors and relations among them [14]. Regional innovation system is made up by companies, universities and other research institutions, intermediaries, government institutions, regional authorities and the third sector (NGOs). Among those entities in region mutual exchange of information, goods, people, knowledge and financial resources is being carried out [2].

One of the factors significantly affecting innovation performance of countries is the investment share on research and development being expressed in proportion to their GDP, or expenditure share on research and development and innovation processes results [1]. Innovation performance assessment has been executed in European Union since 2003. The data are summarized and subsequently published by the European Commission with assistance of using services of organization such as the Eurostat and Joint Research Center. As an assessment tool there is so called Innovation Union Scoreboard, whose output is Summary innovation index (SII).

Goal and methodology. The goal of this paper is by means of selected indicators (outputs) of innovative activities in regions of Slovakia to identify and assess differences in innovation performance in individual regions of Slovakia. In terms of objectives and research content firstly there are presented research and development expenditures, which are transformed into innovative products in particular regions. Consequently, we have set relevant outputs from innovation activities. Selected parameters are assessed in time series of years from 2005 to 2014. Analysis data for the period being assessed have been obtained from the Slovak Statistical Office database [16].

Innovation performance of Slovak regions are assessed and compared in years of 2005-2014, while results of individual regions in these indicators are being considered:

- V3 - creation of new materials, products, equipment or significant improvement (innovation of those already being used);

- V4 - creation of new processes, technological procedures, systems and services (including software) or significant improvement (innovation of those already being used); 
- V5 - creation of projects for implementation of (technical) products or production process innovation;

- V6 - creation of projects for implementation of social (non-technical) innovation in the field of socio-economic and cultural development of society.

To assess the innovation performance of regions in Slovakia we used multi-criteria scoring method. This method is applicable to score Slovak regions at NUTS II level. Within the scoring method for each parameter a value of 100 points is being assigned to region which has achieved the best results in indicators being monitored, and other regions are assigned by a number of points as follows:

$$
b_{i j}=x_{i j} / x_{\text {jmax }} \cdot 100 \text {, }
$$

where $x_{\text {jmax }}$ - highest value of the $j$-th variable; $x_{j}$ - the lowest value of the $j$-th variable; $b_{i j}$ - the scores of the $i$-th regin for the $j$-th variable.

Then we calculate the integral variable $\mathrm{di}_{\mathrm{i}}$, as the arithmetic average of points for individual particular indicators for each region as follows:

$$
d_{i}=\frac{\sum_{i=1}^{m} b_{i j}}{p_{i}},
$$

where $p_{i}$ is the number of evaluated variables.

The best results of observed variable reaches the region in which the integral indicator di reaches the maximum value. To assess the impact of regional innovation activities on competitiveness correlation analysis has been used.

Expenditures on research and development in regions of SR. Based on Member States' average innovation performance as calculated by composite indicator, the Summary Innovation Index, they fall into four different performance groups. Denmark, Finland, Germany, the Netherlands, and Sweden are Innovation Leaders with innovation performance better than the EU average. Austria, Belgium, France, Ireland, Luxembourg, Slovenia, and the UK are Strong Innovators with innovation performance above or close to that of the EU average. The performance of Croatia, Cyprus, Czech Republic, Estonia, Greece, Hungary, Italy, Latvia, Lithuania, Malta, Poland, Portugal, Slovakia, and Spain are ranked below the EU average. These countries are Moderate Innovators. Bulgaria and Romania are Modest Innovators with innovation performance below the EU average.

Despite relatively high economic growth of Slovak economy the progress of research and development (R\&D) and innovation processes is left behind the European average. The reason is not only substandard funding of $R \& D$ processes, but also still strong focus on basic research, relative isolation of Slovak research and still relatively low impact on growth of executed outputs and innovation capacity of Slovak economy.

R\&D funding in Slovakia is characterized by a predominance of public funding, particularly from Structural Funds. This way of funding also predominates in Slovak regions, another aspect that can be clearly seen is the uneven spending on research and development in particular regions, see the Table 1. Expenditures on research and development come from government resources, corporate resources, funding from abroad and other sources. Expenditures on research and development in Slovakia are characterized by long-term underinvestment. One of the reasons was privatization of large enterprises and subsequent separation R\&Ds from practice.

As it can be seen from the Table 1 Bratislava Region significantly differs from all the other regions regarding research and development spending. Expenditures on research and development in this 
region exceeded some regions up to several times, for example the Prešov Region. As a fundamental cause may be mentioned that in Bratislava region there is a scientific research center, where the majority of scientific and research institutions being financed from state budget is concentrated, but on the other hand also a lot of large companies funding research from national sources. Košice region is also in similar situation, but the expenditure values on R\&D are significantly lower than in Bratislava region. Next there is Nitra region, which is slightly behind the Košice region, since 2010 the third spot has been replaced by Žilina Region. Prešov Region is relatively the worst in terms of R\&D spending and in 2011 the last spot was exchanged by Trenčín Region.

Table 1 - Expenditures on research and development from state budget in thousands EUR (formed using data from Statistical Office of Slovak Republic)

\begin{tabular}{|l|c|c|c|c|c|c|c|c|c|c|}
\hline \multicolumn{10}{|c|}{ R\&D expenditures - government and public sources } \\
\hline & $\mathbf{2 0 0 5}$ & $\mathbf{2 0 0 6}$ & $\mathbf{2 0 0 7}$ & $\mathbf{2 0 0 8}$ & $\mathbf{2 0 0 9}$ & $\mathbf{2 0 1 0}$ & $\mathbf{2 0 1 1}$ & $\mathbf{2 0 1 2}$ & $\mathbf{2 0 1 3}$ & $\mathbf{2 0 1 4}$ \\
\hline BSK & 87470 & 95600 & 97113 & 107864 & 100466 & 113640 & 129690 & 138395 & 132969 & 131266 \\
\hline TTSK & 9033 & 2111 & 3961 & 2957 & 2640 & 8326 & 9625 & 8423 & 15338 & 26311 \\
\hline TSK & 5575 & 4108 & 2829 & 4261 & 1261 & 3948 & 2212 & 2153 & 2701 & 3355 \\
\hline NSK & 9443 & 14031 & 15097 & 14130 & 8947 & 13726 & 13378 & 16151 & 12895 & 38727 \\
\hline ZSK & 7274 & 5477 & 5731 & 7404 & 7040 & 16300 & 15167 & 18574 & 20347 & 20248 \\
\hline BBSK & 6920 & 6325 & 6230 & 8358 & 10012 & 12315 & 15536 & 15169 & 12293 & 13848 \\
\hline PSK & 2523 & 2453 & 2474 & 2527 & 2505 & 3698 & 7285 & 7522 & 9445 & 9899 \\
\hline KSK & 13787 & 18610 & 18960 & 18112 & 20328 & 34446 & 40169 & 36914 & 31628 & 33459 \\
\hline Together & $142 \mathbf{0 2 5}$ & $\mathbf{1 4 8 7 1 4}$ & $\mathbf{1 5 2} \mathbf{3 9 3}$ & $\mathbf{1 6 5 6 1 3}$ & $\mathbf{1 5 3 1 9 9}$ & $\mathbf{2 0 6 3 9 9}$ & $\mathbf{2 3 3 0 6 2}$ & $\mathbf{2 4 3} \mathbf{3 0 1}$ & $\mathbf{2 3 7 6 1 6}$ & $\mathbf{2 7 7} \mathbf{1 1 3}$ \\
\hline
\end{tabular}

Notes: BSK - Bratislava Region, TTSK - Trnava Region, TSK - Trenčín Region, NSK - Nitra Region, ŽSK - Žilina Region, BBSK - Banská Bystrica Region, PSK - Prešov Region, KSK - Košice Region

Innovation performance of Slovak regions as a basis for their competitiveness. Innovation policy is an important feature of regional competitiveness. Innovation is the most important factor in regional productivity enhancement, which in the long term is ensuring competitiveness and well-being of region's inhabitants. Until recently, innovation policy was similar to the science and technology policy underlining the push effect that generated innovation. Current innovation policy and networking is a way how to improve regional innovation environment and is focused on communication, cooperation and networking between companies and supporting organizations [9].

An important success factor in regional context is the level of regional innovation potential which has the biggest influence on innovation performance. Regional innovation potential involves many factors and activities and its priority function is to enhance internal and external interactions of particular actors. Regional innovation potential is defined as a way, method of regional innovation capability to utilize and regenerate existing layout source base and create a sustainable competitive advantage from innovation activities.

To determine the linear relationship between the selected innovation output $\mathrm{V} 3$ and the ranking of Slovak Republic in competitiveness according to the World Economic Forum, we used the correlation analysis. To analyze the innovation indicator V3, we used the Shapiro-Wilk normality test. By means of the Shapiro-Wilk test, we assessed whether the parametric correlation coefficient (Pearson coefficient) or the nonparametric coefficient (Spearman or Kendall coefficient) is suitable for the following correlation analysis. We used the Paerson parametric correlation coefficient at last. Logical assumption of our considerations is the existence of interdependence between the Slovak economy ranking in the WEF competitiveness chart and chosen innovation indicator V3. We chose hypothesis as follows:

$\mathrm{H} 1$ : There is a significant linear correlation between the innovation scoreboard V3 and the ranking of Slovak economy in the evaluation reports of World Economic Forum in terms of competitiveness.

From having been stated above it is relevant to establish the power of statistical dependence between innovation scoreboard V3 and the ranking of Slovak economy in competitiveness chart 
(Table 2). That is why, correlation analysis has been executed. Regarding the hypotheses being stated as statistically significant linear relationship it will be presumed the situation when the Pearson correlation coefficient $r$ would reach value higher than 0,5 among indicators being assessed.

Table 2 - Statistical dependence

(formed using data of World Economic Forum, Statistical Office of Slovak Republic)

\begin{tabular}{|c|c|c|}
\hline Year & $\begin{array}{c}\text { Ranking of SR in } \\
\text { competitiveness chart by } \\
\text { WEF }\end{array}$ & $\begin{array}{c}\text { V3 - production of new materials, products, } \\
\text { equipment or substantial improvement } \\
\text { (total in Slovakia) }\end{array}$ \\
\hline 2005 & 41 & 434 \\
\hline 2006 & 37 & 376 \\
\hline 2007 & 41 & 285 \\
\hline 2008 & 46 & 248 \\
\hline 2009 & 47 & 394 \\
\hline 2010 & 60 & 419 \\
\hline 2011 & 69 & 1016 \\
\hline 2012 & 71 & 795 \\
\hline 2013 & 78 & 440 \\
\hline 2014 & 75 & 430 \\
\hline
\end{tabular}

Table 3 - Correlation coefficients

\begin{tabular}{|l|l|l|l|}
\hline$r$ & 0,542 & $t$ & 1,82 \\
\hline$r 2$ & 0,294 & $P(1$-tailed $)$ & 0,053126 \\
\hline \multirow{2}{*}{} & $P(2$-tailed $)$ & 0,106252 \\
\cline { 2 - 4 }
\end{tabular}

The above correlation analysis (Figure 1) shows that the observed dependence is not statistically significant, that hypothesis is confirmed to us. To take into account the fact that the competitiveness and innovation impacted by other factors contained in the pillars of competitiveness. It is implied that the Slovak economy is built on the basis of production factors and not pulled innovations.

Implementation outputs of research and development in region and their assessment. Competitiveness of individual regions, territorially identical with the self-governing units, will be executed by means of regional innovation efficiency assessment as a prerequisite to enhance their competitiveness. Assessment and comparison of selected results in the area of science and research is applied to the data file of self-governing units.

Bratislava region was extracted from assessment because of the reasons described above, Bratislava region has significantly different values and results of scoring method would be distorted. V3 - creation of new materials, products, equipment or significant improvement (innovation of those already being used).

In the number of outputs in Category V3 during the entire period Bratislava region occupies the first spot, their number varies from 118 in 2008 till 802 in 2011. From the other regions only Trnava region crossed the border of 100 outputs in 2010 (112 outputs). Prešov region left behind other regions where during the assessed period there were only 86 outputs in Category V3. Due to the large distance of Bratislava region from other regions, in particular due to very high number of outputs in this region in 2011 and 2013, Bratislava region was excluded from further analysis and assessments by means of scoring method were executed for other regions in Slovakia apart from Bratislava region. The scoring method results for outputs of Category V3 are in Table 5. 


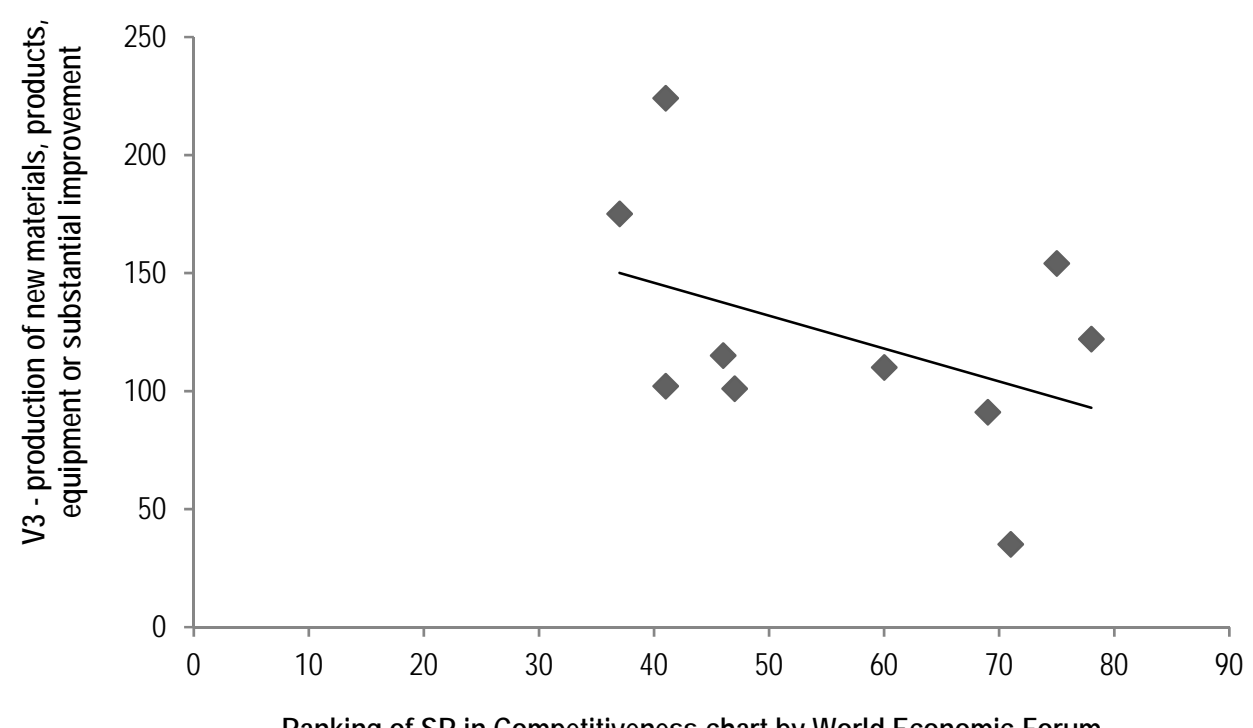

Ranking of SR in Competitiveness chart by World Economic Forum

Figure 1 - Correlation analysis

Table 4 - Number of outputs in Category V3

(formed using data of Statistical Office of Slovak Republic)

\begin{tabular}{|l|c|c|c|c|c|c|c|c|c|c|}
\hline & $\mathbf{2 0 0 5}$ & $\mathbf{2 0 0 6}$ & $\mathbf{2 0 0 7}$ & $\mathbf{2 0 0 8}$ & $\mathbf{2 0 0 9}$ & $\mathbf{2 0 1 0}$ & $\mathbf{2 0 1 1}$ & $\mathbf{2 0 1 2}$ & $\mathbf{2 0 1 3}$ & $\mathbf{2 0 1 4}$ \\
\hline BSK & 205 & 202 & 136 & 118 & 182 & 181 & 802 & 713 & 203 & 192 \\
\hline TTSK & 33 & 17 & 0 & 6 & 54 & 112 & 82 & 19 & 46 & 10 \\
\hline TSK & 81 & 50 & 48 & 18 & 48 & 21 & 23 & 4 & 30 & 49 \\
\hline NSK & 24 & 33 & 30 & 48 & 19 & 20 & 25 & 8 & 19 & 53 \\
\hline ŽSK & 34 & 14 & 13 & 17 & 45 & 54 & 44 & 34 & 82 & 66 \\
\hline BBSK & 13 & 21 & 28 & 9 & 22 & 8 & 12 & 2 & 11 & 15 \\
\hline PSK & 18 & 8 & 10 & 12 & 7 & 5 & 11 & 2 & 8 & 5 \\
\hline KSK & 26 & 31 & 20 & 20 & 17 & 18 & 17 & 13 & 41 & 40 \\
\hline Together & 434 & 376 & 285 & 248 & 394 & 419 & 1016 & 795 & 440 & 430 \\
\hline
\end{tabular}

Table 5 - Number of points for outputs in Category V3

\begin{tabular}{|l|c|c|c|c|c|c|c|c|c|c|}
\hline & $\mathbf{2 0 0 5}$ & $\mathbf{2 0 0 6}$ & $\mathbf{2 0 0 7}$ & $\mathbf{2 0 0 8}$ & $\mathbf{2 0 0 9}$ & $\mathbf{2 0 1 0}$ & $\mathbf{2 0 1 1}$ & $\mathbf{2 0 1 2}$ & $\mathbf{2 0 1 3}$ & $\mathbf{2 0 1 4}$ \\
\hline TTSK & 40,74 & 34,00 & 0,00 & 12,50 & 100,00 & 100,00 & 100,00 & 55,88 & 56,10 & 15,15 \\
\hline TSK & 100,00 & 100,00 & 100,00 & 37,50 & 88,89 & 18,75 & 28,05 & 11,76 & 36,59 & 74,24 \\
\hline NSK & 29,63 & 66,00 & 62,50 & 100,00 & 35,19 & 17,86 & 30,49 & 23,53 & 23,17 & 80,30 \\
\hline ŽSK & 41,98 & 28,00 & 27,08 & 35,42 & 83,33 & 48,21 & 53,66 & 100,00 & 100,00 & 100,00 \\
\hline BBSK & 16,05 & 42,00 & 58,33 & 18,75 & 40,74 & 7,14 & 14,63 & 5,88 & 13,41 & 22,73 \\
\hline PSK & 22,22 & 16,00 & 20,83 & 25,00 & 12,96 & 4,46 & 13,41 & 5,88 & 9,76 & 7,58 \\
\hline KSK & 32,10 & 62,00 & 41,67 & 41,67 & 31,48 & 16,07 & 20,73 & 38,24 & 50,00 & 60,61 \\
\hline
\end{tabular}


From other Slovak regions Žilina Region had the greatest number of executed outcomes in Category V3, this region has been successful especially in the last three years and gained maximum points. During the first three years Trencin region obtained the highest number of points, in 2008 Nitra region and in 2009-2011 it was Trnava region. Overall, Prešov region reached the lowest number of points in 2010. V4 - creation of new processes, technological procedures, systems and services (including software) or significant improvement (innovation of those already being used);

Table 6 - Number of outputs in Category V4

(formed using data of Statistical Office of Slovak Republic)

\begin{tabular}{|l|c|c|c|c|c|c|c|c|c|c|}
\hline & $\mathbf{2 0 0 5}$ & $\mathbf{2 0 0 6}$ & $\mathbf{2 0 0 7}$ & $\mathbf{2 0 0 8}$ & $\mathbf{2 0 0 9}$ & $\mathbf{2 0 1 0}$ & $\mathbf{2 0 1 1}$ & $\mathbf{2 0 1 2}$ & $\mathbf{2 0 1 3}$ & $\mathbf{2 0 1 4}$ \\
\hline BSK & 222 & 207 & 186 & 114 & 172 & 166 & 145 & 12 & 201 & 190 \\
\hline TTSK & 15 & 13 & 17 & 4 & 24 & 12 & 21 & 5 & 23 & 18 \\
\hline TSK & 27 & 13 & 6 & 14 & 39 & 28 & 14 & 0 & 5 & 9 \\
\hline NSK & 25 & 26 & 16 & 20 & 30 & 29 & 23 & 16 & 25 & 32 \\
\hline ŽSK & 72 & 54 & 44 & 34 & 35 & 59 & 57 & 22 & 54 & 54 \\
\hline BBSK & 19 & 37 & 33 & 9 & 62 & 48 & 39 & 17 & 58 & 108 \\
\hline PSK & 3 & 6 & 3 & 0 & 3 & 2 & 11 & 0 & 6 & 3 \\
\hline KSK & 92 & 49 & 36 & 37 & 32 & 47 & 35 & 21 & 87 & 80 \\
\hline Together & $\mathbf{4 7 5}$ & $\mathbf{4 0 5}$ & $\mathbf{3 4 1}$ & $\mathbf{2 3 2}$ & $\mathbf{3 9 7}$ & $\mathbf{3 9 1}$ & $\mathbf{3 4 5}$ & $\mathbf{9 3}$ & $\mathbf{4 5 9}$ & $\mathbf{4 9 4}$ \\
\hline
\end{tabular}

As for the executed outcomes in Category V4, here as well the highest number (for the whole period 1615) was reached in Bratislava region, with the exception of 2012. The limit of 100 outputs was exceeded by Bratislava region and Banská Bystrica Region in 2014. In other regions the number of outputs was substantially lower, in Prešov region only 37 . Behind Bratislava region a large gap is followed by Košice, Žilina and Banská Bystrica regions. These facts were also reflected in scoring (Table 7).

Table 7 - Number of points for outputs in Category V4

\begin{tabular}{|l|c|c|c|c|c|c|c|c|c|c|}
\hline & $\mathbf{2 0 0 5}$ & $\mathbf{2 0 0 6}$ & $\mathbf{2 0 0 7}$ & $\mathbf{2 0 0 8}$ & $\mathbf{2 0 0 9}$ & $\mathbf{2 0 1 0}$ & $\mathbf{2 0 1 1}$ & $\mathbf{2 0 1 2}$ & $\mathbf{2 0 1 3}$ & $\mathbf{2 0 1 4}$ \\
\hline TTSK & 16,30 & 24,07 & 38,64 & 10,81 & 38,71 & 20,34 & 36,84 & 22,73 & 26,44 & 16,67 \\
\hline TSK & 29,35 & 24,07 & 13,64 & 37,84 & 62,90 & 47,46 & 24,56 & 0,00 & 5,75 & 8,33 \\
\hline NSK & 27,17 & 48,15 & 36,36 & 54,05 & 48,39 & 49,15 & 40,35 & 72,73 & 28,74 & 29,63 \\
\hline ŻSK & 78,26 & 100,00 & 100,00 & 91,89 & 56,45 & 100,00 & 100,00 & 100,00 & 62,07 & 50,00 \\
\hline BBSK & 20,65 & 68,52 & 75,00 & 24,32 & 100,00 & 81,36 & 68,42 & 77,27 & 66,67 & 100,00 \\
\hline PSK & 3,26 & 11,11 & 6,82 & 0,00 & 4,84 & 3,39 & 19,30 & 0,00 & 6,90 & 2,78 \\
\hline KSK & 100,00 & 90,74 & 81,82 & 100,00 & 51,61 & 79,66 & 61,40 & 95,45 & 100,00 & 74,07 \\
\hline
\end{tabular}

From other regions except the Bratislava the highest score was received by regions: Kosice (years 2005, 2008, 2013), Zilina (2006, 2007, 2010-2012) and Banská Bystrica (2009 and 2014). The lowest score for the lowest number of outputs in Category V4 gained Prešov Region, which in years 2008 and 2012 had no deliverables in this category, and thus received 0 points. V5 - creation of projects for implementation of (technical) products or production process innovation.

Also in Category V5 the biggest number of outputs is done by Bratislava region, followed by Košice and Žilina regions. In this indicator, however, regional differences are not so significant, and in 2013 and 2014 in Category V5 more outputs than in Bratislava region was done in Košice region, in 2005 in Košice and Prešov regions.

In total, for the whole assessed period Bratislava region is followed by regions of Košice, Prešov and Žilina. The lowest number of outputs is in Nitra region. 
Table 8 - Number of outputs in Category V5

(formed using data of Statistical Office of Slovak Republic)

\begin{tabular}{|l|c|c|c|c|c|c|c|c|c|c|}
\hline & $\mathbf{2 0 0 5}$ & $\mathbf{2 0 0 6}$ & $\mathbf{2 0 0 7}$ & $\mathbf{2 0 0 8}$ & $\mathbf{2 0 0 9}$ & $\mathbf{2 0 1 0}$ & $\mathbf{2 0 1 1}$ & $\mathbf{2 0 1 2}$ & $\mathbf{2 0 1 3}$ & $\mathbf{2 0 1 4}$ \\
\hline BSK & 48 & 49 & 25 & 53 & 38 & 34 & 40 & 14 & 29 & 36 \\
\hline TTSK & 20 & 24 & 3 & 1 & 1 & 6 & 6 & 0 & 3 & 7 \\
\hline TSK & 19 & 12 & 12 & 13 & 12 & 10 & 4 & 0 & 3 & 3 \\
\hline NSK & 1 & 23 & 3 & 1 & 4 & 2 & 2 & 3 & 9 & 6 \\
\hline ŽSK & 21 & 21 & 10 & 10 & 21 & 21 & 15 & 2 & 14 & 15 \\
\hline BBSK & 3 & 4 & 7 & 13 & 3 & 10 & 6 & 2 & 9 & 8 \\
\hline PSK & 55 & 29 & 32 & 10 & 8 & 7 & 7 & 7 & 8 & 9 \\
\hline KSK & 57 & 13 & 10 & 14 & 14 & 20 & 11 & 7 & 47 & 70 \\
\hline Together & $\mathbf{2 2 4}$ & $\mathbf{1 7 5}$ & $\mathbf{1 0 2}$ & $\mathbf{1 1 5}$ & $\mathbf{1 0 1}$ & $\mathbf{1 1 0}$ & $\mathbf{9 1}$ & $\mathbf{3 5}$ & $\mathbf{1 2 2}$ & $\mathbf{1 5 4}$ \\
\hline
\end{tabular}

As it can be seen in Table 9, the highest score (100 points) was gained in Category V5 by regions: Kosice (years 2005, 2008, 2012-2014), Prešov (2006, 2007, 2012), Zilina (2009-2011). In 2012 Trnava and Trencin did not receive any points, since any outputs have not been executed in Category V5. Also in 2005 Nitra Region received low scoring.

Table 9 - Number of points for outputs Category V5

\begin{tabular}{|l|c|c|c|c|c|c|c|c|c|c|}
\hline & $\mathbf{2 0 0 5}$ & $\mathbf{2 0 0 6}$ & $\mathbf{2 0 0 7}$ & $\mathbf{2 0 0 8}$ & $\mathbf{2 0 0 9}$ & $\mathbf{2 0 1 0}$ & $\mathbf{2 0 1 1}$ & $\mathbf{2 0 1 2}$ & $\mathbf{2 0 1 3}$ & $\mathbf{2 0 1 4}$ \\
\hline TTSK & 35,09 & 82,76 & 9,38 & 7,14 & 4,76 & 28,57 & 40,00 & 0,00 & 6,38 & 10,00 \\
\hline TSK & 33,33 & 41,38 & 37,50 & 92,86 & 57,14 & 47,62 & 26,67 & 0,00 & 6,38 & 4,29 \\
\hline NSK & 1,75 & 79,31 & 9,38 & 7,14 & 19,05 & 9,52 & 13,33 & 42,86 & 19,15 & 8,57 \\
\hline ŻSK & 36,84 & 72,41 & 31,25 & 71,43 & 100,00 & 100,00 & 100,00 & 28,57 & 29,79 & 21,43 \\
\hline BBSK & 5,26 & 13,79 & 21,88 & 92,86 & 14,29 & 47,62 & 40,00 & 28,57 & 19,15 & 11,43 \\
\hline PSK & 96,49 & 100,00 & 100,00 & 71,43 & 38,10 & 33,33 & 46,67 & 100,00 & 17,02 & 12,86 \\
\hline KSK & 100,00 & 44,83 & 31,25 & 100,00 & 66,67 & 95,24 & 73,33 & 100,00 & 100,00 & 100,00 \\
\hline
\end{tabular}

V6 - creation of projects for implementation of social (non-technical) innovation in the field of socioeconomic and cultural development of society. In Category V6 the number of outputs development varies considerably, as it can be seen in Table 10, Bratislava Region in 2014 reached 2,517 outcomes in this category; in recent years the number of outputs in this region is ranging in 79-168. Second spot is occupied by Banská Bystrica reaching a large number of outputs particularly in 2005 and 2006, when it overpassed Bratislava region. A significant gap is followed by Košice and Žilina Regions. The smallest number of outputs in Category V6 was done by Trnava Region in 2007, 2011 and 2012 with no output in this category.

Table 10 - Number of outputs in Category V6

(formed using data of Statistical Office of Slovak Republic)

\begin{tabular}{|l|c|c|c|c|c|c|c|c|c|c|}
\hline & $\mathbf{2 0 0 5}$ & $\mathbf{2 0 0 6}$ & $\mathbf{2 0 0 7}$ & $\mathbf{2 0 0 8}$ & $\mathbf{2 0 0 9}$ & $\mathbf{2 0 1 0}$ & $\mathbf{2 0 1 1}$ & $\mathbf{2 0 1 2}$ & $\mathbf{2 0 1 3}$ & $\mathbf{2 0 1 4}$ \\
\hline BSK & 125 & 130 & 94 & 107 & 91 & 92 & 79 & 94 & 168 & 2517 \\
\hline TTSK & 11 & 9 & 0 & 1 & 2 & 6 & 0 & 0 & 6 & 14 \\
\hline TSK & 7 & 10 & 10 & 1 & 2 & 9 & 4 & 3 & 9 & 10 \\
\hline NSK & 18 & 6 & 2 & 8 & 6 & 10 & 12 & 13 & 12 & 45 \\
\hline ŽSK & 28 & 23 & 34 & 28 & 34 & 31 & 34 & 8 & 27 & 22 \\
\hline BBSK & 134 & 152 & 36 & 26 & 71 & 73 & 70 & 51 & 125 & 83 \\
\hline PSK & 3 & 10 & 0 & 0 & 9 & 5 & 4 & 6 & 20 & 10 \\
\hline KSK & 44 & 39 & 46 & 39 & 18 & 31 & 23 & 16 & 35 & 23 \\
\hline Together & $\mathbf{3 7 0}$ & $\mathbf{3 7 9}$ & $\mathbf{2 2 2}$ & $\mathbf{2 1 0}$ & $\mathbf{2 3 3}$ & $\mathbf{2 5 7}$ & $\mathbf{2 2 6}$ & $\mathbf{1 9 1}$ & $\mathbf{4 0 2}$ & $\mathbf{2 7 2 4}$ \\
\hline
\end{tabular}


Є. Іванова, М. Кордос. Конкурентоспроможність та інноваційна діяльність у регіонах Словацької Республіки

Table 11 - Number of points for outputs in Category V6

\begin{tabular}{|l|c|c|c|c|c|c|c|c|c|c|}
\hline & $\mathbf{2 0 0 5}$ & $\mathbf{2 0 0 6}$ & $\mathbf{2 0 0 7}$ & $\mathbf{2 0 0 8}$ & $\mathbf{2 0 0 9}$ & $\mathbf{2 0 1 0}$ & $\mathbf{2 0 1 1}$ & $\mathbf{2 0 1 2}$ & $\mathbf{2 0 1 3}$ & $\mathbf{2 0 1 4}$ \\
\hline TTSK & 8,21 & 5,92 & 0,00 & 2,56 & 2,82 & 8,22 & 0,00 & 0,00 & 4,80 & 16,87 \\
\hline TSK & 5,22 & 6,58 & 21,74 & 2,56 & 2,82 & 12,33 & 5,71 & 5,88 & 7,20 & 12,05 \\
\hline NSK & 13,43 & 3,95 & 4,35 & 20,51 & 8,45 & 13,70 & 17,14 & 25,49 & 9,60 & 54,22 \\
\hline ŽSK & 20,90 & 15,13 & 73,91 & 71,79 & 47,89 & 42,47 & 48,57 & 15,69 & 21,60 & 26,51 \\
\hline BBSK & 100,00 & 100,00 & 78,26 & 66,67 & 100,00 & 100,00 & 100,00 & 100,00 & 100,00 & 100,00 \\
\hline PSK & 2,24 & 6,58 & 0,00 & 0,00 & 12,68 & 6,85 & 5,71 & 11,76 & 16,00 & 12,05 \\
\hline KSK & 32,84 & 25,66 & 100,00 & 100,00 & 25,35 & 42,47 & 32,86 & 31,37 & 28,00 & 27,71 \\
\hline
\end{tabular}

Scoring has showed that the maximum number of points 100 in most years was received by Banská Bystrica Region, except the years of 2007 and 2008, when Košice region got the best scoring. In addition to Trnava region also Prešov region gained zero points in 2007 and 2008.

\section{Table 12 - Total points for outputs in Category V3-V6}

\begin{tabular}{|l|c|c|c|c|c|c|c|c|c|c|}
\hline & $\mathbf{2 0 0 5}$ & $\mathbf{2 0 0 6}$ & $\mathbf{2 0 0 7}$ & $\mathbf{2 0 0 8}$ & $\mathbf{2 0 0 9}$ & $\mathbf{2 0 1 0}$ & $\mathbf{2 0 1 1}$ & $\mathbf{2 0 1 2}$ & $\mathbf{2 0 1 3}$ & $\mathbf{2 0 1 4}$ \\
\hline TTSK & 100,34 & 146,75 & 48,01 & 33,02 & 146,29 & 157,13 & 176,84 & 78,61 & 93,72 & 58,69 \\
\hline TSK & 167,91 & 172,03 & 172,88 & 170,76 & 211,75 & 126,16 & 84,99 & 17,65 & 55,92 & 98,91 \\
\hline NSK & 71,99 & 197,41 & 112,59 & 181,71 & 111,07 & 90,23 & 101,31 & 164,60 & 80,66 & 172,72 \\
\hline ŽSK & 177,97 & 215,55 & 232,25 & 270,53 & 287,67 & 290,68 & 302,23 & 244,26 & 213,46 & 197,93 \\
\hline BBSK & 141,96 & 224,31 & 233,47 & 202,60 & 255,03 & 236,12 & 223,06 & 211,73 & 199,23 & 234,16 \\
\hline PSK & 124,21 & 133,69 & 127,65 & 96,43 & 68,57 & 48,04 & 85,09 & 117,65 & 49,67 & 35,26 \\
\hline KSK & 264,93 & 223,23 & 254,73 & 341,67 & 175,11 & 233,44 & 188,33 & 265,06 & 278,00 & 262,39 \\
\hline
\end{tabular}

While assessing the total number of points obtained in Categories of executed outcomes V3-V6 in the years of 2005-2014, it can be implied that in most years Košice Region has gained the most points (in 2008 to 341.67 pts.). The value of 300 points in 2011 was slightly exceeded by Žilina Region, which overpassed Košice region in 2009-2011. In 2006 Banská Bystrica region gained the highest number of points. Overall, Nitra region in 2012 gained the lowest number of points.

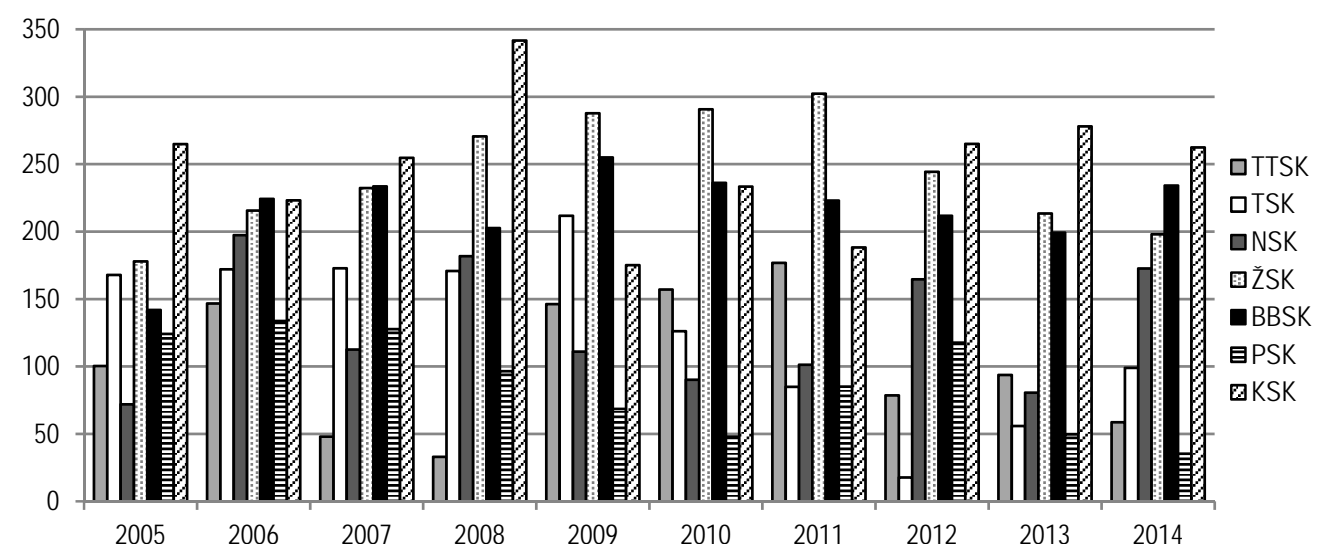

Figure 2 - Total category scoring of regions in Categories V3-V6 


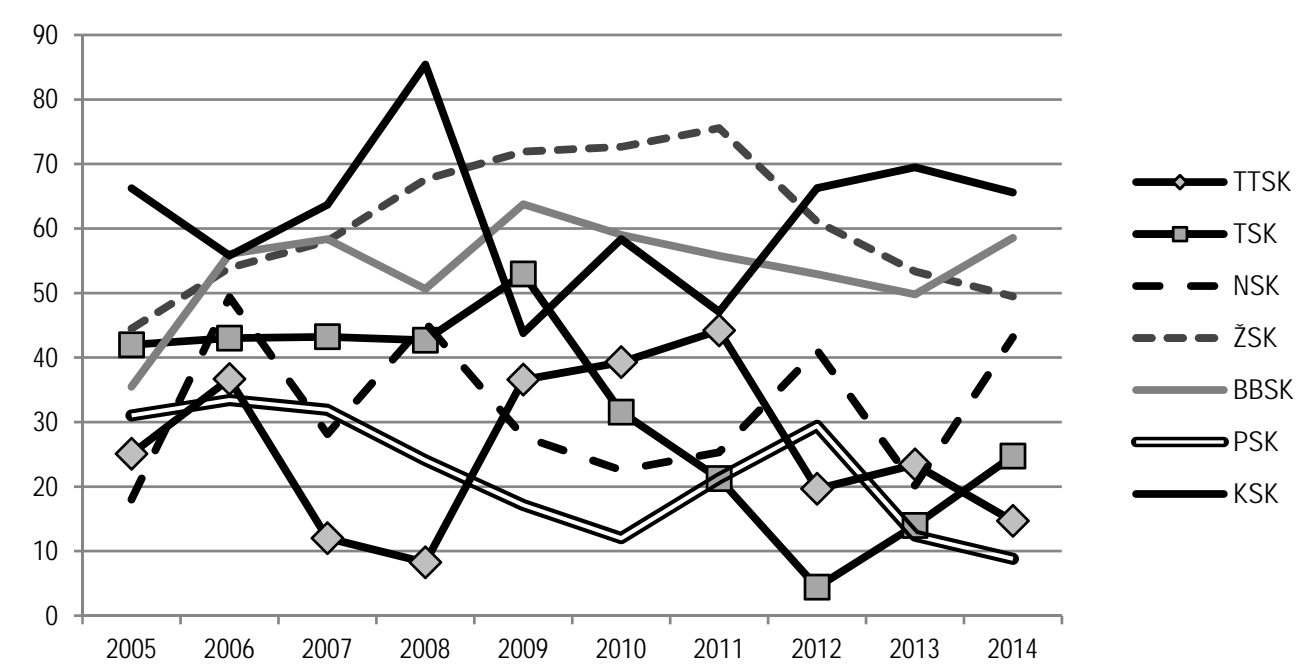

Figure 3 - Graphic illustration of assessment scoring development in Slovak regions

Average scoring obtained by each region for executed outputs in Categories V3-V6 and total average scoring have been also recalculated (Table 13).

Table 13 - Average scoring of regions for each category output

\begin{tabular}{|l|c|c|c|c|c|}
\hline & V3 & V4 & V5 & V6 & Total average \\
\hline TTSK & 51,44 & 25,15 & 22,41 & 4,94 & 25,98 \\
\hline TSK & 59,58 & 25,39 & 34,72 & 8,21 & 31,97 \\
\hline NSK & 46,87 & 43,47 & 21,01 & 17,08 & 32,11 \\
\hline ŽSK & 61,77 & 83,87 & 59,17 & 38,45 & 60,81 \\
\hline BBSK & 23,97 & 68,22 & 29,48 & 94,49 & 54,04 \\
\hline PSK & 13,81 & 5,84 & 61,59 & 7,39 & 22,16 \\
\hline KSK & 39,46 & 83,48 & 81,13 & 44,63 & 62,17 \\
\hline
\end{tabular}

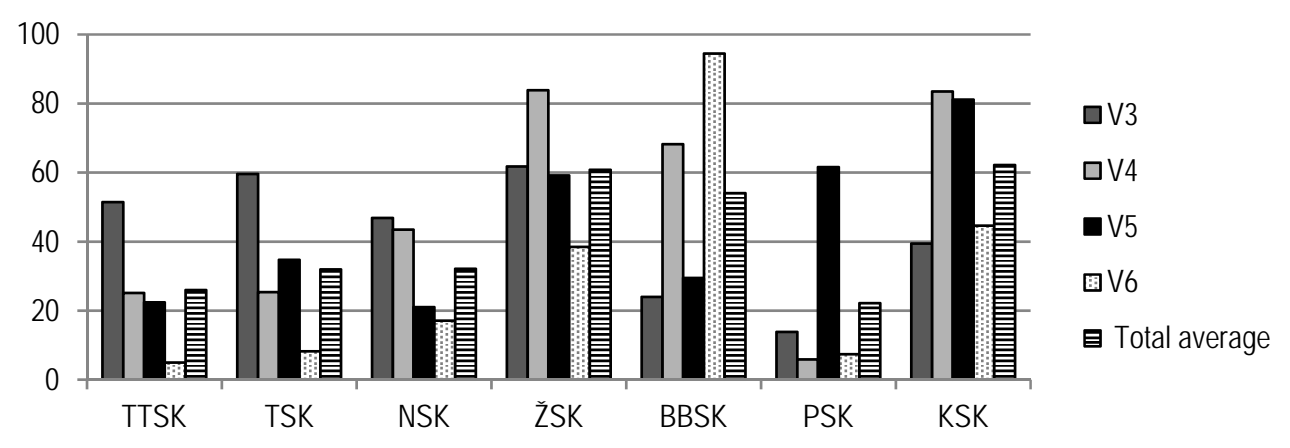

Figure 4 - Graphic illustration of average scoring of regions for each category output 
Regions of Western Slovakia (Trnava, Trenčín and Nitra) received the highest scoring for the number of outputs in Category V3. Žilina and Košice region achieved the best results in Category V4. Banská Bystrica region is the most successful in Category V6, Prešov in Category V5. The best average for all output categories has gained Košice region, closely followed by Žilina region, followed by Banská Bystrica. Prešov and Trnava regions have got the lowest average scoring.

If we confront the average assessment for all output categories with expenditures on research and development in individual regions then Košice region, which has the highest R\&D expenditures during the whole examined period has also the highest outcomes in all categories, except V6 (Figure 3). On the contrary, Prešov Region, which has the lowest R\&D expenditures till 2011, is reaching the best results in average scoring in Category 5, when it ranked the second spot after Košice region. Banska Bystrica region that in terms of $R \& D$ expenditure has relatively good scores till 2011 (the 4th place) in average scoring has the best results in $\mathrm{V} 6$ Category output.

Conclusion and directions for further research. Innovation performance is one of the factors that has an impact on development in various areas of social life by its synergistic effect, it affects the economic performance and competitiveness at all levels. In terms of our research on regional innovation performance, we can see that regional disparities in social and economic indicators are presented. Based on the correlation analyses having been executed we state that Slovakia belongs to the group of countries where the competitiveness is not pulled by innovation.

In this paper we have shown that innovation performance is one of the factors that by its synergistic effect has an impact on development in various areas of social life, is affecting the economic performance and competitiveness at all levels. In terms of our research on regional innovation performance, we can see that regional disparities in social and economic indicators can be narrowed by being engaged in cooperation with all important stakeholders in region such as companies, clusters exploiting new technologies based on innovation, patents, knowledge and added-value. The rapid internationalization of technology means that firms need to monitor both their domestic and their foreign technological environments. For many industries, technology is of the utmost importance and can determine whether firms prosper or fall by the wayside. That also applies to regions and states. Only economy as an active member of international division of labor, producing high-tech products based on innovations is able to achieve sustainable economic growth. Failing to do so, economy will be caught in the world economy periphery having no sources to secure economic development for sufficient quality of life. Technology is a double-edged sword for business offering many opportunities but also challenges. On the one hand, it opens up a variety of opportunities for business in terms of new products, processes, and markets. On the other, it leaves firms more open to a range of competitive threats such as takeover, increased competition and even to the theft of their technologies.

We arrived to the conclusion how technology refers to ideas and knowledge that business can exploit commercially and assure regional sustainable development. The sources of new ideas on which regions can call are many and varied, ranging from universities and research institutes to competitors, customers and suppliers, and to employees. For example The European Union has also launched several integrated programs of research to help backwoods regions to catch up with the developed ones in the application of modern technology.

Finally we can summarize that globalization and technology make foreign sources of new ideas more accessible and have made it easier for business tap in to foreign sources through, for example, cross-border R\&D partnerships. Innovation tends to be concentrated in big firms operating in the hightech manufacturing sector. The rate of innovation varies from firm to firm, sector by sector and country to country. Some firms in particular regions generally spend more on R\&D and take out more patents than firms based elsewhere. Firms are motivated to innovate by increasingly fierce competition from rivals, 
both domestic and foreign, other elements in the supply chain, developments in the ICT sector, and the policies pursued by governments. Technology offers opportunities to business organizations to increase their profits and growth through the introduction of new and improved goods and services and through changes to their production processes. Technology also helps firms to restructure their global patterns of production through investment in low cost locations or by sub-contracting to cheaper suppliers. However, technology can also pose threats and challenges for firms particularly if they allow themselves to fall behind their competitors.

1. Balaz, P., \& Zabojnik, S. (2010). Contemporary Development of the Commodity Markets - Consequences and Challenges for the Revitalization of the World Economy. Ekonomicky casopis, 58(9), 938-957 [in English].

2. Cihelkova E., \& Hnat P. (2008). Future of the European Union within the new regionalism context. Politicka ekonomie, 56(1), 67-79 [in English].

3. Drucker, P.F. (1993). Postcapitalist Society. New York: HerperCollins Publishers [in English].

4. Edquist, C. (1997). Systems of Innovation: Technologies, Institutions and Organisations. London: Pinter Publishers [in English].

5. European Commission (2002). Regional clusters in Europe. Observatory of European SMEs 2002 / No. 3. Retrieved from http://ec.europa.eu/regional_policy/archive/innovation/pdf/ibrary/regional_clusters.pdf [in English].

6. Fojtikova, L. (2014). Performance and growth of the Eurozone export. 17th International conference enterprise and competitive environment 2014, Book Series: Procedia Economics and Finance, Vol. 12, Brno: Mendel Univ, Fac Business \& Econ. 154-163 [in English].

7. Havierniková, K. (2014). Convergence of the Slovak Republic regions. Proceedings of the 2nd international conference on European integration 2014. Ostrava : VŠB, 2014. 228-235 [in English].

8. Kačírková, M. (2009). Formovanie spolupracujúceho regionálneho inovačného prostredia. Bratislava: Ekonomický ústav SAV [in Slovak].

9. Kačírková, M. (2011). Výskumné zhluky a vedecké parky ako faktor inovačného rozvoja regiónov. Bratislava: EÚ SAV [in Slovak].

10. Krugman, P. (1994). Competitiveness: A Dangerous Obsession. Foreign Affairs, 73(3), 28-44 [in English].

11. Lundvall, B-A. (ed.) (1992). National Systems of Innovation: Towards a Theory of Innovation and Interactive learning. London: Pinter Publishers [in English]

12. Masárová, J. (2015). Comparison of performance of Visegrad group regions, In: Vadyba : Journal of management, 26, 101-108 [in English].

13. Martin, R. (1999). The new "geographical turn" in economics: some critical reflections. Cambridge Journal of Economics, 23(1), 65-91 [in English].

14. Porter, M.E. (1990). The Competitive Advantage of Nations. New York: The Free Press [in English].

15. Ručínska, S. (2008). Konkurencieschopnost' regiónov s dôrazom na inovácie. Transfer inovácií, 12, 181-185. Retrieved from http://www.sjf.tuke.sk/transferinovacii/pages/archiv/transfer/12-2008/pdf/181-185.pdf [in Slovak].

16. Schumpeter, J.A. (1934). The Theory of Economic Development. An Inquiry into Profits, Capital, Credit, Interest, and the Business Cycle. Cambridge: Harvard University Press [in English].

17. Slovak Statistical Office. (2015). www.statistics.sk. Retrieved from http://www.statistics.sk/pls/elisw/ metainfo.explorer?cmd=open\&s=1002\&sso=2 [in English].

18. Skokan, K. (2004). Konkurenceschopnost, inovace a klastry. Ostrava: Repronis [in Polish].

19. Teece, D.J., Pisano, G., \& Shuen, A. (1997). Dynamic Capabilities and Strategic Management, Strategic Management Journal, 18(7), 509-533 [in English].

20. Tödtling, F., \& Trippl, M. (2005). One size fits all? Towards a differentiated regional innovation policy approach, Research Policy, 34(8), 1203-1219 [in English].

21. Urbančíková, N. Burger, P. (2010). Miera regionalizácie inovačných politík a jej vplyv na inovačnú výkonnost' regiónov. E+M Ekonomie a management, 13(1), 23-36 [in Slovak].

22. Valenta, F. (1969). Tvưrčí aktivita, inovace, efekty. 1. vyd. Praha: Svoboda [in Czech].

€. Іванова, PhD, асистент кафедри економіки, факультет соціальних та економічних відносин, Університет Олександра Дубчека в Тренчині (м. Тренчин, Словацька Республіка);

M. Kордос, PhD, асистент кафедри державного управління та регіональної економіки, факультет соціальних та економічних відносин, Університет Олександра Дубчека в Тренчині (м. Тренчин, Словацька Республіка) 
Конкурентоспроможність та інноваційна діяльність у регіонах Словацької Республіки

У статті розглядаються питання конкурентоспроможності та інноваційної діяльності, що є взаємозв'язаними економічними категоріями та мають синергетичний ефект у різних сферах економічного та соціального життя. Ïх аналіз та оцінювання можуть бути здійснені на різних рівнях, таких як бізнес-рівень, регіональний, національний та міжнародний рівень. Національна конкурентоспроможність і продуктивність інновацій є результатом взаємодії зацікавлених сторін бізнесу та на регіональному рівні. Метою иієї статті $є$ аналіз інноваційної діяльності на регіональному рівні, тобто на рівні окремих регіонів Словаччини на основі обраних результатів інноваційних процесів у сфрерах науки, досліджень і розробок. Результати оцінювання інноваційної діяльності показують значні відмінності за регіонами, які досліджувалися, що також знаходить своє відображення в їх економічних відмінностях та рівні конкурентоспроможності.

Ключові слова: інновації, інноваційна діяльність, конкурентоспроможність, регіон, дослідження, розвиток.

E. Иванова, PhD, ассистент кафедры экономики, факультет социальных и экономических отношений, Университет Александра Дубчека в Тренчине (г. Тренчин, Словацкая Республика);

M. Кордос, PhD, ассистент кафедры государственного управления и региональной экономики, факультет социальных и экономических отношений, Университет Александра Дубчека в Тренчине (г. Тренчин, Словацкая Республика)

Конкурентоспособность и инновационная деятельность в регионах Словацкой Республики

В статье рассматриваются вопросы конкурентоспособности и инновационной деятельности, которые являются взаимосвязанными экономическими категориями и имеют синергетический эффект в различных сферах экономической и социальной жизни. Их анализ и оценивание могут быть осуществлены на разных уровнях, таких как бизнес-уровень, региональный, национальный и международный уровень. Национальная конкурентоспособность и продуктивность инноваций являются результатом взаимодействия заинтересованных сторон бизнеса и на региональной уровне. Целью этой статьи является анализ инновационной деятельности на региональном уровне, то есть на уровне отдельных регионов Словакии на основании выбранных результатов инновационных процессов в сферах науки, исследований и разработок. Результаты оценивания инновационной деятельности показывают значительные различия по регионам, которые исследовались, что также находит отражение в их экономических отличиях и уровне конкурентоспособности.

Ключевые слова: инновации, инновационная деятельность, конкурентоспособность, регион, исследование, развитие.

Отримано 07.05.2016p. 